\title{
Dampak Putusan Mahkamah Agung Nomor 365 K/PID 2012 Terhadap Kinerja Dokter di Wilayah III Cirebon
}

\author{
Endang Sutrisno; Elya Kusuma Dewi
}

\section{DATA NASKAH}

Masuk: 5 Mei 2016

Diterima: 21 September 2016

Terbit: 8 Desember 2016

KORESPONDEN PENULIS:

Universitas Swadaya Gunung Jati Cirebon

Jalan Pemuda No. 32, Sunyaragi, Kesambi, Kota Cirebon, Jawa Barat 45132

E-mail: endangsutrisno94@gmail.com

\section{ABSTRACT}

The embodiment of right legal should be complementary and it is not mutually exclusive the essence of law which lies in its legal characteristics of institutions that support and protect those values. The existence of law must be able to provide the embodiment of the values into reality, and applies in the process of working of law. Legal norms that regulate doctors as in Act 29 year 2004 on the Practice of Medicine provides a strict definition about professional standard, which describes a minimum competence (knowledge, skill and professional attitude) which is made by professional organizations that should be mastered by an individual to carry out his or her professional activities in the community independently. Therefore, in practicing a profession, physicians should be based on these norms because they are responsible for their profession in case of negligence and mistakes that can lead to legal liability, and requires legal process that could result in an administrative, civil or criminal. A court ruling determines it. Supreme Court Decision No. $365 \mathrm{~K} /$ Pid 2012, is one forms of legal liability as an expression of physicians in running their profession, though in the end the verdict, it can impact on their performance.

Keywords: legal norms, doctor's profession, legal liability.

\section{ABSTRAK}

Perwujudan hukum yang benar harus saling melengkapi dan tidak saling mengecualikan hakikat dari hukum terletak pada karakteristik dari hukumnya sebagai institusi yang menunjang dan melindungi nilai-nilai, hingga eksistensi hukum harus mampu memberikan perwujudan nilainilai menjadi kenyataan dan perwujudan tersebut teraplikasikan dalam proses bekerjanya hukum. Norma hukum yang mengatur dokter yaitu Undang-Undang No.29 tahun 2004 tentang Praktek Kedokteran memberikan suatu pendefinisian secara tegas mengenai standar profesi, 
yaitu batasan kemampuan (knowledge, sklill and profesional attitude) minimal yang harus dikuasai oleh seorang individu untuk dapat melakukan kegiatan profesionalnya pada masyarakat secara mandiri yang dibuat oleh organisasi profesi. Untuk itu, dalam menjalankan profesi dokter harus berdasarkan pada ketentuan norma tersebut sebab dokter dituntut pertanggungjawaban dalam menjalankan profesinya, bilamana terjadi hal-hal yang disebabkan oleh kelalaian dan kesalahannya dapat menimbulkan pertanggungjawaban hukum sehingga dituntut adanya proses hukum yang dapat berakibat administratif, perdata atau pidana, putusan pengadilan yang dapat menentukan hal ini. Putusan Mahkamah Agung Nomor 365 K/Pid 2012, salah satu bentuk pertanggungjawaban hukum yang harus dibebankan sebagai bentuk perwujudan dokter dalam menjalan profesinya, sekalipun pada akhirnya dengan putusan tersebut dapat berdampak pada kinerja dokter.

Kata Kunci: Norma Hukum; Profesi Dokter; Pertanggungjawaban Hukum

\section{PENDAhULUAN}

Aksi solidaritas dari ribuan dokter yang melakukan longmarch dari Tugu Proklamasi, Bundaran Hotel Indonesia, dan ke kantor Mahkamah Agung pada Rabu, 27 November 2013 menjadi perhatian kita semua. Aksi ini dipicu oleh vonis Mahkamah Agung pada tanggal 18 september 2012 yang menghukum dokter Dewa Ayu Sasiary Prawan, dr. Hendry Simanjutak dan dr. Hendy Siagian dengan vonis 10 bulanpenjara.

Kasus dokter Ayu dan kawan-kawan berawal dari mening-galnya pasien yang mereka tangani, Julia Fransiska Maketey, di Rumah Sakit R.D. Kandou Malalayang, Manado, Sulawesi Utara, pada 10 April 2010.

Berikut ini kronologi kasus penangkapan dokter Ayu dan kedua orang temanya yang juga ikut dihukum atas tuduhan kasus malpraktek menurut keterangan dari Ketua Umum Perkumpulan Obstetri dan Ginekologi Indonesia (POGI), Dr Nurdadi Saleh, SpOG seperti dilansir dari Liputan6:

\section{Tanggal 10 April 2010}

Korban, Julia Fransiska Makatey (25) merupakan wanita yang sedang hamil anak keduanya. la masuk ke RS Dr Kandau Manado atas rujukan puskesmas. Pada waktu itu, ia didiagnosis sudah dalam tahap persalinan pembukaan dua.

Namun setelah delapan jam masuk tahap persalinan, tidak ada kemajuan dan justru malah muncul tanda-tanda gawat janin, sehingga ketika itu diputuskan untuk dilakukan operasi caesar darurat."Saat itu terlihat tanda tanda gawat janin, terjadi mekonium atau bayi mengeluarkan feses saat persalinan sehingga diputuskan melakukan bedah sesar," ujarnya.

Tapi yang terjadi menurut dr Nurdadi, pada waktu sayatan pertama dimulai, pasien mengeluarkan darah yang berwarna kehitaman. Dokter menyatakan, itu adalah tanda bahwa pasien kurang oksigen.

"Tapi setelah itu bayi berhasil dikeluarkan, namun pasca operasi kondisi pasien semakin memburuk dan sekitar 20 menit kemudian, ia dinyatakan meninggal dunia," ungkap Nurdadi, seperti ditulis Senin (18/11/2013).

\section{Tanggal 15 September 2011}

Atas kasus ini, tim dokter yang terdiri atas dr Ayu, dr Hendi Siagian dan dr Hendry Simanjuntak, dituntut Jaksa Penuntut Umum (JPU) hukuman 10 bulan penjara karena laporan malpraktik keluarga korban. Namun Pengadilan Negeri (PN) Manado menyatakan ketiga terdakwa tidak bersalah dan bebas murni.

"Dari hasil otopsi ditemukan bahwa sebab kematiannya adalah karena adanya emboli udara, sehingga mengganggu peredaran darah yang sebelumnya tidak diketahui oleh dokter. Emboli udara atau gelembung udara ini ada pada bilik kanan jantung pasien. Dengan bukti ini PN Manado memutuskan bebas murni," tutur dr Nurdadi.

Tapi ternyata kasus ini masih bergulir karena jaksa mengajukan kasasi ke Mahkamah Agung yang kemudian dikabulkan.

\section{18 September 2012}

dr. Dewa Ayu dan dua dokter lainnya yakni dr Hendry Simanjuntak dan dr Hendy Siagian akhirnya masuk daftar pencarian orang (DPO).

\section{11 Februari 2013}

Keberatan atas keputusan tersebut, PB POGI melayangkan surat ke Mahkamah Agung dan dinyatakan akan diajukan upaya Peninjauan Kembali (PK).

Dalam surat keberatan tersebut, POGI menyatakan bahwa 


\section{MEDIA
HUKUM}

putusan PN Manado menyebutkan ketiga terdakwa tidak terbukti secara sah dan meyakinkan kalau ketiga dokter tidak bersalah melakukan tindak pidana. Sementara itu, Majelis Kehormatan dan Etika Profesi Kedokteran (MKEK) menyatakan tidak ditemukan adanya kesalahan atau kelalaian para terdakwa dalam melakukan operasi pada pasien.

\section{8 November 2013}

dr Dewa Ayu Sasiary Prawan (38), satu diantara terpidana kasus malapraktik akhirnya diputuskan bersalah oleh Mahkamah Agung dengan putusan 10 bulan penjara. la diciduk di tempat praktiknya di Rumah Sakit Ibu dan Anak Permata Hati, Balikpapan Kalimantan Timur (Kaltim) oleh tim dari Kejaksaan Agung (Kejagung) dan Kejari Manado sekitar pukul 11.04 WITA.

Kemudian keluarga Julia menggugat ke pengadilan negeri. Hasilnya, dr. Ayu dan kedua rekannya dinyatakan tidak bersalah. Namun, di tingkat kasasi, ketiga dokter tersebut divonis 10 (sepuluh) bulan penjara. Majelis hakim kasasi memvonis Dewa Ayu Sasiary serta dua rekannya, Hendy Siagian dan Hendry Simanjuntak, bersalah saat menangani Julia Fransiska Maketey. Julia akhirnya meninggal saat melahirkan. Berikut ini pertimbangan majelis kasasi seperti yang tercantum dalam putusan yang dirumuskan dalam sidang 18 September 2012:

1. Julia dinyatakan dalam keadaan darurat pada pukul 18.30 WITA, padahal seharusnya dinyatakan darurat sejak ia masuk rumah sakit pada pagi hari.

2. Sebagian tindakan medis Ayu dan rekan-rekannya tidak dimasukkan ke rekam medis.

3. Ayu tidak mengetahui pemasangan infus dan jenis obat infus yang diberikan kepada korban.

4. Meski Ayu menugasi Hendy memberi tahu rencana tindakan kepada pasien dan keluarganya, Hendy tidak melakukannya. Ia malah menyerahkan lembar persetujuan tindakan yang telah ditandatangani Julia kepada Ayu, tapi ternyata tanda tangan di dalamnya palsu.

5. Tidak ada koordinasi yang baik dalam tim Ayu saat melakukan tindakan medis.

6. Tidak ada persiapan jika korban mendadak mengalami keadaan darurat.
Aksi solidaritas dokter-dokter ini tidak hanya di Jakarta, tetapi berdampak pula di Wilayah 3 (tiga) Cirebon. Contoh kecil dapat kita lihat di RSUD Gunung Jati Cirebon. Puluhan dokter ikut mogok praktik, meskipun Direktur Rumah Sakit menyatakan tidak akan menelantarkan pasiennya, tetapi faktanya banyak ada pasien yang tidak dapat memeriksakan kandungan tidak bisa memeriksakan kandungannya (www.Sindonews.com, 27/11/2013).

Putusan Kasasi ini menjadi pembelajaran yang berarti bagi para dokter, bahwa tidak ada yang kebal hukum dan dalam melakukan tindakan harus berhati-hati dan sesuai prosedur. Meskipun kemudian kita ketahui dalam Putusan pertama, banding dan PK semuanya menyatakan bahwa dr. Ayu dkk tidak bersalah dan bebas dari hukuman, tetapi kemudian beberapa responden kami menyatakan bahwa ada rasa was-was dalam menangani pasiennya.

Proses pembuatan putusan oleh hakim di pengadilan, merupakan suatu proses yang kompleks dan sulit dilakukan sehingga memerlukan pelatihan, pengalaman dan kebijaksanaan. Menurut Artidjo Alkostar, sebagai figur sentral penegak hukum, para hakim memiliki kewajiban moral dan tanggung jawab profesional untuk menguasai knowledge, memiliki skill berupa legal technical capacity dan kapasitas moral yang standar. Dengan adanya kecukupan pengetahuan dan ketrampilan teknis, para hakim dalam memutus suatu perkara akan dapat memberikan pertimbangan hukum (legal reasoning) yang tepat dan benar. Jika suatu putusan pengadilan tidak cukup mempertimbangkan (onvoldoende gemotiveerd) tentang hal-hal yang relevan secara yuridis dan sah muncul di persidangan, maka akan terasa adanya kejanggalan yang akan menimbulkan matinya akal sehat (the death of common sense) (M.Syamsudin, 2012:41).

\section{RUMUSAN MASALAH}

1. Bagaimanakah dampak dari Putusan Mahkamah Agung Nomor 365/Pid/2012 terhadap kinerja dokter?

2. Bagaimanakah aspek hukum kinerja dokter yang melakukan tindakan tidak sesuai SOP ketika dalam keadaan darurat dikaitkan dengan KUH Pidana?

\section{METODE PENELITIAN}

Metode penelitian yang digunakan adalah pendekatan yuridis normatif. Penelitian hukum normatif merupakan 
penelitian yang mengutamakan data kepustakaan, yaitu penelitian terhadap data sekunder (Ronny Hanitijo Soemitro, 2004:24). Pendekatan normatif yaitu mendekati masalah yang diteliti dengan mendasarkan pada norma yang berlaku, apakah putusan Kasasi Mahkamah Agung telah sesuai dengan hukum yang berlaku. Peneliti berusaha menemukan hukum in concreto. Artinya bahwa peneliti ingin mengetahui implementasi dari perundang-undangan yang berlaku, yaitu dengan menganalisis data sekunder dan meneliti taraf sinkronisasi baik secara vertikal maupun horizontal dengan peraturan hukum tertulis. Melelui penelitian normatif pula, dalam ilmu hukum yang objeknya adalah norma (hukum), penelitian hukum (de beovening-het de bedrijven) dilakukan untuk membuktikan apakah bentuk penormaan yang dituangkan dalam suatu ketentuan hukum positif dalam praktik hukum telah sesuai atau merefleksikan prinsip-prinsip hukum yang ingin menciptakan keadilan (Johnny Ibrahim, 2006:48).

\section{HASIL PENELITIAN DAN ANALISIS}

\section{D.1.Dampak dari Putusan Mahkamah Agung}

\section{Nomor 365/Pid/2012 terhadap Kinerja}

\section{Dokter di Wilayah Kota Cirebon, Kabupaten}

Cirebon, Kabupaten Majalengka, Kabupaten

\section{Indramayu, dan Kabupaten Kuningan}

Temuan penelitian yang dilakukan dengan mendasarkan pada observasi langsung kepada beberapa dokter maupun hasil tinjauan pustaka, menemukan dampak yang besar akibat dari adanya Putusan Mahkamah Agung Nomor 365/Pid/ 2012.

Pada tingkat pertama, permasalahan malpraktik dr.Ayu dkk ini diputus bebas murni oleh Pengadilan Negeri Manado, yang kemudian pada Tingkat Kasasi dr.Ayu dkk dinyatakan bersalah dan dihukum selama 10 (sepuluh) bulan. Dalam hal ini menurut saksi ahli dari kedokteran menyatakan bahwa Seksio Sesaria telah dilakukan sesuai dengan standard yang berlaku.

Selain untuk solidaritas sesama dokter, para dokter juga merasa khawatir, bahwa profesinya rawan sekali dengan tindak pidana. Oleh karenanya, pada tanggal 27 Novemper 2013 secara rame-rame dokter seluruh Indonesia mengadakan protes, demo di Jakarta dan mogok kerja. Begitu pula di wilayah Kota Cirebon, Kabupaten Cirebon, Kabupaten Majalengka, Kabupaten Indramayu, dan Kabupaten Kuningan, dokter yang tidak mengikuti demo di Jakarta melakukan mogok kerja yang berimbas pula pada pelayanan kesehatan yang diberikan kepada msyarakat dalam bentuk telantarnya pasien. Penanganan pasien pada saat itu menurun drastis, terbukti dari data yang penulis dapat dari hasil wawancara beberapa rumah Sakit di Wilayah Kota Cirebon, Kabupaten Cirebon, Kabupaten Majalengka, Kabupaten Indramayu, dan Kabupaten Kuningan Jawa Barat, pelayanan kesehatan dapat dikatakan lumpuh akibat dari dokter melangsungkan protes/demo solidaritas. Dari Rumah Sakit Gunung Jati di bagian poliklinik kebidanan tidak satupun pasien yang terdaftar berobat pada hari itu.

Hasil wawancara dan kuesioner beberapa dokter hampir semuanya sama mengatakan bahwa, ada rasa kekhawatiran dokter dalam menangani pasiennya karena takut dituntut pidana malpraktik kedokteran, dimana menurut mereka, sudah merasa benar dalam menangani pasiennya.

Selain para dokter kemudian bersikap sangat hati-hati dalam penanganan pasien, para dokter juga berharap aturanaturan hukum untuk perlindungan dokter jelas, agar para dokter merasa aman dalam menangani pasien.

Dokter mengambil keputusan praktek kedokteran defensif yang menyebar ke banyak bidang kedokteran klinis dan dipandang sebagai faktor utama dalam peningkatan biaya perawatan kesehatan. Hal ini terjadi karena karena dokter melakukan kecemasan berlebihan terhadap pasien umum dari pada pasien keluarga dokter yang lebih jarang melakukan tuntutan medis (On Line, Dampak Putusan Mahkamah Agung Nomor 365K/Pid/2012.tanggal 15 Februari 2015).

Contoh Defensif Medicine atau praktek kedokteran defensif. Seorang dokter telah melakukan prosedur medis yang sesuai, saat dokter menerima pasien 3 (tiga) tahun dengan keluhan demam berdarah. Pada saat hari pertama demam, orang tua pasien bersikeras meminta pemeriksaan darah terhadap dokter tetapi dokter sudah menjelaskan kepada pasien bahwa pemeriksaan darah untuk melihat penyakit DBD pada hari pertama dan kedua tidak terlalu informatif. Dan sudah menjelaskan kepada orang tua pasien 


\section{MEDIA
HUKUM}

bahwa kalaupun terjadi demam berdarah pada hari pertama kedua pada penderita DBD tidak ada penanganan khusus karena masih belum menunjukkan manifestasi yang berat. Disarankan untuk melakukan cek darah pada hari ketiga. Disarankan hari pertama dan kedua dan ketiga harus kontrol ke dokter untuk memonitor keadaan pasien. Tetapi orang tua pasien tidak melakukan kontrol pada hari kedua maupun hari ketiga karena anaknnya dianggap sudah sehat karena demam pada hari ketiga dan keempat baik. Namun tragisnya pada hari kelima anaknya semakin lemah dan semakin memburuk dan orang tua mengannggap karena kelelahan biasa. Saat hari keenam keadaan semakin memburuk dan anaknya meninggal sebelum dibawa ke rumah sakit. Melihat keadaan seperti itu orang tuanya dengan latar belakang persepsi medis yang terbatas dan emosi terhadap dokternya melakukan gugatan terhadap dokter karena melakukan malpraktek karena saat hari pertama meminta pemeriksaan darah tidak dikabulkan dokternya. Dengan melihat kronologis di atas, dokter telah melakukan sesuai prosedur medis yang benar sesuai kaidah ilmu kedokteran tetapi karena pasien membandel tidak mengindahkan kontrol ke dokter menyalahkan kematian anakanya kepada dokter tersebut. Orang tua menyalahkan kepada dokter tentang pemeriksaan darah pada hari pertama yang menurut persepsi medis tidak perlu dan tidak informatif bila dilakukan (On Line, Dampak Putusan Mahkamah Agung Nomor 365K/Pid/2012.tanggal 15 Februari 2015).

Pada kasus tersebut meski sudah ada SOP di institusi tempat dokter bekerja tidak mengungkapkan secara detail pemeriksaan laboratorium hari pertama secara detail, tetapi kemudian dokter mengalami trauma apabila menangani pasien demam. Trauma gugatan malpraktik yang salah arah sebelumnya dokter praktek kedokteran defensif yang justru merugikan pasien. Bayangkan bila pemeriksaan darah tidak diperlukan tetapi kemudian pasien harus merogoh uang ratusan ribu bahkan sampai jutaan hanya karena defensif medicine karena dokter takut di kriminalisasi. Hasil penelitian dengan melalui wawancara dengan dokter-dokter di wilayah penelitian, sepanjang kurun waktu tanggal 20 April 2015 sampai dengan tanggal 30 April 2015 bahwa dokter-dokter sangat berhati-hati dalam memberikan jawaban/pelayanan kesehatan terhadap pasien yang mengerti tentang hukum.
Dampak putusan Mahkamah Agung ini tidak hanya kepada dokter saja, tetapi juga berdampak pada pasien. Dari data yang Peneliti lakukan diperoleh informasi bahwa pada tanggal 27 November 2013, dimana hari itu dokter banyak yang demo dan terjadi mogok kerja, maka pasien-pasien yang membutuhkan pelayanan dokter menjadi tidak mendapatkannya. Ada pasien asal Ciamis yang sudah dijadwalkan menjalani operasi usus buntu di sebuah rumah sakit, namun kemudian batal dioperasi karena dokternya ikut dalam aksi solidaritas (On Line HKLI: Dokter yang Mogok Berpotensi Langgar 4 Peraturan, www.okezone.com).

Pada sisi lain kehadiran negara dalam persoalan kesehatan menjadi masalah yang urgen, mengingat eksistensi tanggungjawab negara terhadap jaminan pemenuhan dan perlindungan hak manusia tidak terlepas dari prinsip-prinsip pokok hak asasi manusia. Prinsip tersebut menjadi ukuran standar pelaksanaan hak asasi manusia secara internasional dan nasional meliputi hak asasi manusia yang tidak bisa dibagi (indivisibility) (M.Syafi'ie, 2012: 685).

Hak atas kesehatan merupakan salah satu hak konstitusional warga negara yang diatur dalam UndangUndang Dasar Negara Republik Indonesia Tahun 1945, sebagai sebuah dokumen formal yang berisi: hasil perjuangan politik bangsa di waktu lampau; pandangan tokoh-tokoh bangsa yang hendak diwujudkan, baik untuk waktu sekarang, maupun untuk masa masa yang akan datang; suatu keinginan (kehendak) dengan mana perkembangan kehidupan ketatanegaraan bangsa hendak dipimpin; tingkat-tingkat tertinggi perkembangan ketatanegaraan bangsa (Sri Soemantri, 2001:48).

Penting untuk mendorong pengaturan secara normatif dalam konstitusi. Tidak kalah penting dengan hak tersebut adalah soal pelaksanaannya yang melandasi kehidupan berbangsa dan bernegara. Meskipun dalam Undang-Undang Dasar Negara Republik Indonesia Tahun 1945 pasca amandemen telah mengatur lebih baik dalam soal kewajiban asasi, tetapi salah satu yang penting untuk diatur ulang adalah memperkuat landasan tanggung jawab hak asasi manusia yang harus dilakukan oleh pemerintah (state responsibility), yakni soal kewajiban bertindak dan kewajiban untuk memaksimalkan sumber dayanya untuk pemenuhan hak asasi manusia (Winda Wijayanti, 2013:512). Ketentuan hukum 
normatif dalam Pasal 4 Undang-Undang Kesehatan telah menyebutkan bahwa setiap orang berhak atas kesehatan, hal ini merupakan hak konstitusional sebagai hak atas kesehatan.

\section{D.2. Aspek Hukum Kinerja Dokter yang melakukan Tindakan Tidak Sesuai SOP Ketika dalam Keadaan Darurat dikaitkan dengan Kitab Undang-Undang Hukum \\ Pidana}

Tujuan dari dikeluarkannya peraturan tentang Kesehatan adalah untuk memberikan perlindungan kepada dokter maupun pasien dari segi hukum. Begitu pula dengan adanya Undang-Undang Nomor: 29 Tahun 2004 tentang praktik Kedokteran yang mengatakan, Pengaturan praktik kedokteran bertujuan untuk:

1) Memberikan perlindungan kepada pasien;

2) Mempertahankan dan meningkatkan mutu pelayanan medis yang diberikan oleh dokter dan dokter gigi;

3) Memberikan kepastian hukum kepada masyarakat, dokter dan dokter gigi.

Pasien berhak mendapatkan informasi yang lengkap terkait dengan penyakitnya dan pengobatan yang akan dilakukan oleh dokter. Rahasia kedokteran adalah milik pasien, berkasnya adalah milik rumah sakit, dan rahasia kedokteran hanya dapat diberikan atas izin pasien. Selain itu bahwa pasien juga berhak menuntut ganti rugi terhadap dokter yang menangani apabila dalam penanganinya menimbulkan kerugian akibat kesalahan atau kelalaian dalam pelayanan kesehatan yang diterimanya, termasuk juga berlaku bagi dokter yang membocorkan rahasia kedokteran.

Gugatan secara perdata-pun dapat timbul dalam hal pertanggungjawaban dokter, gugatan untuk meminta pertanggungjawaban dokter tersebut bersumber pada dua dasar hukum yaitu: berdasarkan pada wanprestasi (contractual liability) sebagaimana diatur dalam Pasal 1239 KUH Perdata; dan berdasarkan perbuatan melawan hukum (onrechtsmatigedaad) sesuai dengan ketentuan Pasal 1365 Kitab Undang-Undang Hukum Perdata (Nendar Darkani, 2011:18).

Dalam Undang-Undang Nomor 29 Tahun 2004 tentang
Praktik Kedokteran, dicantumkan tentang hak dokter dan pasien sebagai berikut:

1. Hak Pasien

a. Mendapatkan penjelasan secara lengkap tentang tindakan medis.

Diagnosis dan tata cara tindakan medis.

Tujuan tindakan medis yang dilakukan.

Alternatif tindakan lain dan resikonya.

Risiko dan kompilasi yang mungkin terjadi.

Prognosis terhadap tindakan yang dilakukan.

b. Meminta pendapat dokter atau dokter gigi lain.

c. Mendapatkan pelayanan sesuai dengan kebutuhan medis.

d. Menolak tindakan medis.

e. Mendapatkan isi rekam medis.

2. Kewajiban Pasien

i. Memberikan informasi yang lengkap dan jujur tentang masalah kesehatannya.

ii. Mematuhi nasehat dan petunjuk dokter dan dokter gigi.

iii. Mematuhi ketentuan yang berlaku disarana pelayanan kesehatan.

iv. Memberikan imbalan jasa atas pelayanan yang diterima.

3. Hak Dokter

a. Memperoleh perlindungan hukum sepanjang melaksanakan tugas sesuai dengan standar profesi dan standar prosedur operasional.

b. Memberikan pelayanan medis menurut standar profesi dan standar prosedur operasional.

c. Memperoleh informasi yang lengkap dan jujur dari pasien atau keluarganya.

d. Menerima imbalan jasa.

4. Kewajiban Dokter

a. Memberikan pelayanan medis sesuai dengan standar profesi dan standar prosedur operasional serta kebutuhan medis pasien.

b. Merujuk pasien ke dokter atau dokter gigi lain yang mempunyai keahlian atau kemampuan yang lebih baik, apabila tidak mampu melakukan suatu pemeriksaan atau pengobatan.

c. Merahasiakan segala sesuatu yang diketahuinya 


\section{MEDIA
HUKUM}

tentang pasien, bahkan juga setelah pasien meninggal dunia.

d. Melakukan pertolongan darurat atas dasar perikemanusiaan, kecuali bila ia yakin ada orang lain yang bertugas dan mampu melakukannya; dan menambah ilmu pengetahuan dan mengiikuti perkembangan ilmu kedokteran atau kedokteran gigi.

J. Guwandi menyatakan bahwa medical error sebagai akibat tindakan medis yang dilakukan dapat dibedakan sebagai berikut (Anny Isfandyarie \& Fachrizal Afandi, 2010:51):

a) Kegagalan/ketidakberhasilan terapi dalam tindakan operasi, yang antara lain disebabkan oleh:

Terjadinya kompilasi (penyulit).

Kecelakaan (surgical mishap).

- Kecelakaan anesthesi (reaksi hypersensitif terhadap obat anesthesi dan sebagainya).

b) Ketidakberhasilan/kegagalan dalam pemberian pengobatan, yang dapat dikarenakan hal-hal sebagai berikut:

- Komplikasi dari pengobatan sebagaimana yang dialami pasien Rusmini.

Kecelakaan medis.

Kesalahan menentukan diagnosis.

Kesalahan dalam memilih obat.

Dalam kasus dimana dokter harus melakukan tindakan emergency, yang mana harus dilakukan tindakan dengan segera, hal ini tentu kurang teapat apabila diterapkan sama dengan kasus yang tidak memerlukan tindakan emergency. Karena tindakan yang harus segera, misal: pasien dalam keadaan tidak sadar dan harus menanganan segera karena menyangkut nyawa, sedangkan keluarga pasien tidak ada ditempat, maka dokter akan melakukan tindakan emergency tersebut tanpa persetujuan pihak keluarga.

Dalam Pasal 304 Kitab Undang-Undang Hukum Pidana menyebutkan:

"Barangsiapa dengan sengaja menempatkan atau membiarkan seorang dalam keadaan sengsara, padahal menurut hukum yang berlaku baginya atau menurut persetujuan, dia wajibmemberi kehidupan, perawatan atau pemeliharaan kepada orang itu, diancam dengan pidana penjara paling lama dua tahun delapan bulan atau denda paling banyak tiga ratus rupiah".
Dalam Pasal 351 Kitab Undang-Undang Hukum Pidana menyebutkan:

"Barangsiapa ketika menyaksikan bahwa ada orang yang sedang menghadapi maut, tidak memberi pertolongan yang dapat diberikan padanya tanpa selayaknya menimbulkan bahaya bagi dirinya atau orang lain, diancam jika kemudian orang itu meninggal, dengan kurungan paling lama tiga ulan atau denda paling banyak tiga ratus rupiah".

Adanya aturan tentang kedokteran dan adanya pasalpasal Kitab Undang-Undang Hukum Pidana yang tidak saling sinkron dengan aturan kedokteran ini tentunya membuat ketakutan para dokter dalam menangani pasiennya. Tujuan dokter tentunya membuat sembuh pasiennya, tetapi jika kemudian berujung pada pidana tentunya sangat menakutkan bagi para dokter.

Selain itu, bahwa ancaman pidana dalam penyelenggaraan praktik kedokteran yang tercantum di dalam Kitab Undang-Undang Hukum Pidana yang dapat dikenakan kepada dokter/dokter gigi yang memenuhi unsur-unsur rumusan tindak pidana dalam Kitab Undang-Undang Hukum Pidana, antara lain:

1. Pelanggaran kewajiban dokter/dokter gigi;

2. Kejahatan terhadap nama baik seseorang;

3. Kejahatan terhadap kesusilaan;

4. Kejahatan terhadap pemalsuan;

5. Kejahatan terhadap tubuh dan nyawa.

Pelanggaran terhadap kewajiban dan larangan yang dilakukan dengan sengaja oleh dokter atau dokter gigi yang melakukan praktik kedokteran maupun sarana pelayanan kesehatan tempat dokter atau dokter gigi melakukan praktik kedokteran, dapat dikenakan sanksi pidana yang tercantum di dalam Pasal 27 sampai Pasal 80 Undang-Undang Praktik Kedokteran.

Ketentuan pidana pada Undang-Undang Praktik Kedokteran pada umumnya menganut sistem alternatif yang memberikan kebebasan kepada hakim untuk memilih salah satu jenis pidana yang tercantum dalam rumusan tindak pidana yang bersangkutan. Terkait upaya mewujudkan sistem hukum yang efektif perlu penataan kembali kelembagaan hukum yang didukung oleh kualitas sumber daya manusia 
dan kultur dan kesadaran hukum masyarakat yang terus meningkat, seiring dengan, pembaharuan materi hukum yang terstruktur secara harmonis tanpa pertentangan dan tumpang tindih dan hukum secara terus menerus diperbaharui sesuai dengan tuntutan perkembangan kebutuhan (Bahria Prentha, 2011:177). Dalam perkembangan sistem hukum Indonesia sejak masa pemerintahan kolonial sampai dengan saat ini Romli Atmasasmita, membedakan dalam 4 (empat) model hukum, yaitu pertama, model hukum kolonial yang sangat represif; kedua, model hukum pembangunan; ketiga, model hukum progresif; dan keempat, model hukum integratif(Romli Atmasasmita, 2012:5).

Ancaman pidana bukan menjadi alasan orang tidak mengetahui adanya hukum. Dampak dari adanya ancaman pidana bagi tenaga kesehatan dalam Undang-Undang Kesehatan bahwa setiap orang dianggap tahu akan hukum atau undang-undang (een ieder wordt geacht de wet/ het recht te kennen). Ketidaktahuan seseorang akan hukum tidak dapat dijadikan alasan pemaaf atau membebaskan orang itu dari tuntutan hukum (ignorantia iuris neminem excusat/ ignorance of the law excuses no man)(R. Herlambang Perdana, 2012: 22). Perlu disadari bahwa untuk menciptakan keadilan hukum diperlukan peran aktif dari berbagai pihak mulai dari pembentukan produk hukum hingga penegakan produk hukum (Yunus Bureni, 2013:125). Hukum memiliki kedaulatan yang berpijak pada kedaulatan rakyat, dapat dibuat "hipotesis"(Bambang Widjojanto, 2012:30) bahwa kedaulatan hukum bukanlah ditujukan semata-mata untuk kepentingan hukum itu sendiri, tetapi justru harus ditujukan dan berpihak bagi kepentingan masyarakat.

Dokter dan dokter gigi sebagai subjek hukum dalam melakukan praktik kedokteran tunduk pada ketentuan yang ada di dalam Kitab Undang-Undang Hukum Pidana, UndangUndang Nomor 36 Tahun 2009 Tentang Kesehatan serta ditambah dengan Undang-Undang Nomor 29 tahun 2004 tentang Praktek Kedokteran, sehingga hubungan hukum yang ditimbulkan oleh dokter atau dokter gigi dalam praktik kedokteran harus sesuai dan tidak melanggar aturan tersebut.

Dalam proses pelaksanaan penuntutan pidana dalam kasus praktik kedokteran berlaku pula Kitab Undang-Undang
Hukum Acara Pidana, sehingga prosedur yang dikenakan pada dokter atau dokter gigi saat proses penuntutan tersebut sama dengan proses pelaksanaan penuntutan pidana pada kasus-kasus lain.

\section{KESIMPULAN DAN SARAN}

\section{Kesimpulan}

1. Adanya Putusan Mahkamah Agung Nomor: 365/Pid/ 2012, yang menghukum dr.Ayu dkk selama sepuluh bulan, sangat berdampak pada dokter-dokter di seluruh Indonesia terutama dokter-dokter di wilayah Kota Cirebon, Kabupaten Cirebon, Kabupaten Majalengka, Kabupaten Indramayu, dan Kabupaten Kuningan Cirebon. Dalam perkaraini, bahwa saksi ahli dari kedokteran mengatakan tidak ada malpraktik dan SOP kedokteran telah ditempuh, tetapi ternyata hukum telah memberikan konsekuensi yang lain. Untuk itu, dokter-dokter merasa ada kekhawatiran dalam penanganan pasiennya karena takut terkena pidana dan berdampak pada kinerja dokter yang kemudian menjadi sangat hati-hati dan menjadi kurang maksimal karena adanya rasa takut/khawatir.

2. Dokter yang melaksanakan tugasnya tidak sesuai dengan SOP ketika dalam keadaan darurat dikaitkan dengan Kitab Undang-Undang Hukum Pidana, tidak kemudian langsung dapat dipidana. Untuk dipidananya seseorang tentunya ketika seseorang tersebut dapat mem pertanggungjawabkan perbuatannya. Ada asas pembenar dan pemaaf yang harusdibuktikanoleh seorang dokter ketika menangani pasiennya yang dalam keadaan darurat tanpa dokter tersebut melakukan sesuai SOP.

\section{Saran}

Dokter dan dokter gigi sebagai subjek hukum dalam melakukan praktik kedokteran tunduk pada ketentuan yang ada di dalam Kitab Undang-Undang Hukum Pidana, UndangUndang Nomor 36 Tahun 2009 tentang Kesehatan serta ditambah dengan Undang-Undang Nomor 29 Tahun 2004 tentang Praktek Kedokteran, oleh karenanya aturan tersebut selain harus diperjelas, penegakan hukum harus ditegakkan secara proporsional. 


\section{DAFTAR PUSTAKA}

\section{Buku-Buku}

Guwandi, J, 2009, Pengantar Ilmu Hukum Medik Eु BioEtika, Fakultas Kedokteran Universitas Indonesia, Jakarta.

Hanitijo Soemitro, Ronny 2004, Metodologi Penelitian Hukum, Ghalia Indonesia, Jakarta.

Isfandyarie, Anny - Afandi - Fachrizal, 2006, Tanggung Jawab Hukum dan Sanksi Bagi Dokter Buku ke II, Prestasi Pustaka Raya, Jakarta.

Ibrahim, Johnny, 2006, Teori $\mathcal{E}$ Metodologi Penelitian Hukum Normatif, Bayumedia Publishing, Malang.

\section{Jurnal}

Atmasasmita, Romli, 2012, Tiga Paradigma Hukum dalam Pembangunan Nasional", Jurnal Hukum Prioris Fakultas Hukum Universitas Trisakti, Vol.3 Nomor 1.

Bureni, Yunus, Juni 2013, Moralitas Pembentukan Peraturan Daerah dalam Upaya Mencapai Keadilan Substantif (Morality Formation of Local Regulations in An Effort to Ensure Substantive Justice)",Jurnal Legislasi Indonesia, Vol.10 Nomor 2, Direktorat Jenderal Peraturan Perundang-undangan Kementerian Hukum dan HAM RI.

Darkani, Nendar, 2011, Tanggung Jawab Dokter terhadap Rekam Medis dalam Dimensi Hukum, Jurnal Hukum Responsif Fakultas Hukum Universitas Swadaya Gunung Jati, Volume 01, No.1/ 2011.

Prentha, Bahria, Agustus 2011, Filsafat Hukum dan NilaiNilai Pancasila, Jurnal Ilmiah Kebijakan Hukum, Vol.5 No.2, Pusat Pengkajian dan Pengembangan Kebijakan Kementerian Hukum dan HAM RI.

Soemantri, Sri, September-November 2001, UndangUndang Dasar 1945 Kedudukan dan Artinya dalam Kehidupan Bernegara",Jurnal Demokrasi dan HAM, Vol.1 No.4, the Habibie Center (THC).

Syamsudin, M, 2012, Keadilan Subtantif yang Terabaikan dalam Sengketa Sita Jaminan: Kajian Putusan No.42/ PDT/2011/PT. Y, Jurnal Yudisial, Vol - V/ No-01/ April/ 2012.

Syafi'ie, M, Desember 2012, Intrumentasi Hukum HAM, Pembentukan Lembaga Perlindungan HAM di Indonesia dan Peran Mahkamah Konstitusi,Jurnal Konstitusi, Vol.9 No.4, Kepaniteraan dan Kesekretariatan Jenderal
Mahkamah Konstitusi RI.

Widjojanto, Bambang, 2012, Negara Hukum, Korupsi dan Hak Asasi Manusia: Suatu Kajian Awal”, Jurnal Hukum Prioris Fakultas Hukum Universitas Trisakti, Vol.3 No.1 Tahun 2012.

Wiratraman, R.Herlambang Perdana,2012, Bahasa Hukum dan Alienasi Keadilan", Jong Indonesia, No.7 Tahun III September 2012, Majalah Online PPI Belanda.

Wijayanti, Winda, September 2013, Eksistensi Hukum Perawat sebagai Tenaga Kesehatan Selain Tenaga Kefarmasian terhadap Hak Atas Pelayanan Kesehatan,Jurnal Dinamika Hukum Fakultas Hukum Universitas Jenderal Soedirman Purwokerto, Vol.13 Nomor 3.

\section{Sumber-Sumber Lain}

www.Sindonews.com, 27/11/2013.

On Line HKLI: Dokter yang Mogok Berpotensi Langgar 4 Peraturan, www.okezone.com 